\title{
Radiocarbon and Oxidizable Carbon Ratio Dates From the Camp Joy Mound (41UR144) in Northeast Texas
}

Timothy K. Perttula

Heritage Research Center, Stephen F. Austin State University

Mike Turner

Bo Nelson

Heritage Research Center, Stephen F. Austin State University

Follow this and additional works at: https://scholarworks.sfasu.edu/ita

Part of the American Material Culture Commons, Archaeological Anthropology Commons, Environmental Studies Commons, Other American Studies Commons, Other Arts and Humanities Commons, Other History of Art, Architecture, and Archaeology Commons, and the United States History Commons

Tell us how this article helped you.

This Article is brought to you for free and open access by the Center for Regional Heritage Research at SFA ScholarWorks. It has been accepted for inclusion in Index of Texas Archaeology: Open Access Gray Literature from the Lone Star State by an authorized editor of SFA ScholarWorks. For more information, please contact cdsscholarworks@sfasu.edu. 


\section{Radiocarbon and Oxidizable Carbon Ratio Dates From the Camp Joy Mound}

(41UR144) in Northeast Texas

\section{Creative Commons License}

\section{(c) (1) \&}

This work is licensed under a Creative Commons Attribution-NonCommercial 4.0 International License 


\title{
RADIOCARBON AND OXIDIZABLE CARBON RATIO DATES FROM THE CAMP JOY MOUND (41UR144) IN NORTHEAST TEXAS
}

\author{
Timothy K. Perttula, Mike Turner, and Bo Nelson
}

\section{INTRODUCTION}

The Camp Joy Mound (41UR144) is a looted Caddo mound on property owned by the U.S. Army Corps of Engineers, Fort Worth District, at Lake o' the Pines (Turner 1993; Perttula et al. 1996). Although only a small number of artifacts have been found in the mound deposits principally a few brushed sherds - it appears to be a Late Caddoan period construction with two mound platforms, separated by extensive charcoal lenses from one (or more) burned Caddoan struc- ture exposed in a larger looters trench. To ascertain the age of the burned Caddoan structure that stood on the main mound platform, we obtained two charcoal samples and two oxidizable carbon ratio (OCR) samples (see Frink 1994 for information on the OCR procedure for dating archeological features) of sediments from the charcoal lens in our freshly cleaned profile of the trench cutting across the mound (Turner 1993:Figure 4).

\section{Provenience and Results}

The charcoal samples were collected from about $60-70 \mathrm{~cm}$ below surface from two sides of the large looters trench. The northern profile sample (Sample \#3) was collected where the top mound and the underlying platform mound are conjoined, whereas the eastern profile sample (Sample \#2) was near the base of the top mound, about $10 \mathrm{~cm}$ above Sample \#3. The calibrated radiocarbon dates are A.D. $1495-1605$ (0.83 probability; Beta-84435, northern side of profile trench sample \#3) and A.D. $1515-1592$ (0.42 probability) and A.D. 1621 - 1675 (0.39 probability;
Beta-84436, eastern side of profile trench sample \#2).

The two OCR samples came from the southern trench profile $(57 \mathrm{~cm}$ below surface, correlating in depth with radiocarbon sample \#3) and the northern trench profile $(70 \mathrm{~cm}$ below surface, correlating in depth with radiocarbon sample \#2). The OCR date from the southern trench profile is $296 \pm 8$ years BP, rounded up to $300 \pm$ 10 years BP (ACT \#2218) or A.D. $1650 \pm$ 10 , and the other OCR date is $420 \pm 12$ years BP (ACT \#2219), rounded to A.D. 
$1530 \pm 10$, from the northern trench profile.

There is a strong correlation between the calibrated age estimates for the burned structure at the Camp Joy Mound from the radiocarbon dates and the two OCR dates. The radiocarbon and OCR dates from $c a$. 57 and $60 \mathrm{~cm}$ bs are cal AD $1495-1605$ and A.D. 1640 - 1660, respectively, whereas the slightly deeper radiocarbon and OCR samples $(c a .70 \mathrm{~cm})$ are cal $\mathrm{AD}$ 1515 - 1592 or cal AD $1621-1673$ and A.D. 1520 - 1540, respectively. Based on the overlapping ages of the four samples, indicating their broad contemporaneity, we estimate that the structure buried by the second mound platform at Camp Joy was burned and then capped with soils between ca. A.D. $1550-1560$.

The four dates provide good evidence that the Camp Joy Mound was in use in the $16^{\text {th }}$ and $17^{\text {th }}$ centuries, a period of time when it has generally been agreed that Caddoan peoples in Northeast Texas outside the Red River Valley were no longer building and using earthen mounds (cf. Thurmond 1990; Perttula 1992). Further investigations of the mound are planned to examine the profile in more detail, and collect additional radiocarbon and OCR samples for dating, particularly to evaluate the possibility that the charcoal lenses exposed in the looters trench are from two or more temporally sequent Titus phase structures, one slightly above the other.

\section{Dating the Late Caddoan Period in Northeast Texas}

The Late Caddoan period is thought to date from ca. A.D. $1350 / 1400-1680$ (Story 1990:334; Perttula 1992). In the Cypress Creek basin of the Northeast Texas Pineywoods, both the Whelan and Titus phases fall into this period. A few calibrated radiocarbon dates for the Whelan phase indicate it began around A.D. 1350, whereas the Titus phase is still rather imprecisely dated from $c a$. A.D. 1450 to at least the early 1600 s (Thurmond 1990; Perttula 1992:102-107). The chronological span of the two phases is poorly developed because of few radiocarbon dates for the Late Caddoan period sequence (Thurmond 1990:Table 60; Story 1990:Table 81). Only 22 radiocarbon dates have been obtained from Whelan and Titus phase components (Table 1), including those from the Camp Joy Mound.

As Table 1 shows, radiocarbon dates from assumed Whelan and Titus phase components overlap at the 1-sigma range, lending some credence to Thurmond's (1990:225) assertion that "the existing radiocarbon data base from the Cypress basin is unsuitable for use in an interpretation of the local culture history". Nevertheless, the most reasonable (i.e., with probability distributions at one sigma or greater than 0.76 ) of the recent calibrated 1-sigma radiocarbon dates from 
Table 1. Late Caddoan Radiocarbon Dates from the Northeast Texas Pineywoods and Post Oak Savanna.

\begin{tabular}{|c|c|c|c|c|c|c|}
\hline Stte & Provenlence & Lab $\#$ & $\begin{array}{l}{ }^{14} \mathrm{CAge} \\
\text { (B.P.) } \\
\end{array}$ & $\begin{array}{c}\text { Corrected Age } \\
\text { (B.P.) } \\
\end{array}$ & $\begin{array}{l}\text { Callbrated Age } \\
\text { (B,P.) }{ }^{\text {** }}\end{array}$ & Reference \\
\hline \multicolumn{7}{|c|}{ WHELAN PHASE (after Thurmond 1990) } \\
\hline \multirow[t]{5}{*}{ UR10 } & $\begin{array}{l}\text { House } 4 \text { under } \\
\text { Mound D }\end{array}$ & $T x-84$ & $490 \pm 100$ & $490 \pm 108$ & $\begin{array}{l}\text { AD 1385-1515 (0.72) } \\
\text { AD 1311-1352 (0.17) } \\
A D ~ 1593-1620(0.10)\end{array}$ & $\begin{array}{l}\text { Jelks and Tunnell } \\
\text { 1959; Tamers et al. } \\
1964\end{array}$ \\
\hline & Mound B fill & $\mathrm{T} \times-238$ & $265 \pm 65$ & $265 \pm 76$ & $\begin{array}{l}\mathrm{AD} 1511-1599(0.39) \\
\mathrm{AD} 1616-1680(0.34) \\
\mathrm{AD} 1756-1804(0.20)\end{array}$ & $\begin{array}{l}\text { Jelks and Tunnell } \\
1959 ; \text { Pearson et al. } \\
1966\end{array}$ \\
\hline & Mound $\mathrm{C}$ fill & Tx-239 & $330 \pm 110$ & $330 \pm 117$ & AD $1444-1668(0.98)$ & $\begin{array}{l}\text { Jelks and Tunnell } \\
\text { 1959; Pearson et al. } \\
1966\end{array}$ \\
\hline & Mound C fill & $\mathrm{Tx}-240$ & $555 \pm 70$ & $555 \pm 81$ & $\begin{array}{l}\text { AD 1382-1437 (0.56) } \\
\text { AD 1308-1357 (0.44) }\end{array}$ & $\begin{array}{l}\text { Jelks and Tunnell } \\
\text { 1959; Pearson et al. } \\
1966\end{array}$ \\
\hline & $\begin{array}{l}\text { House 4, beam } \\
\text { above floor, Md. } \\
\text { D }\end{array}$ & $\mathrm{Tx}-241$ & $345 \pm 75$ & $345 \pm 85$ & $\mathrm{AD} 1479-1641(1.00)$ & $\begin{array}{l}\text { Jelks and Tunnell } \\
1959 ; \text { Pearson et al. } \\
1966\end{array}$ \\
\hline UR11 & $\begin{array}{l}\text { latest of } 2 \\
\text { structures under } \\
\text { mound [House } \\
\text { B] }\end{array}$ & $\mathrm{Tx}-83$ & $480 \pm 110$ & $480 \pm 117$ & $\begin{array}{l}\mathrm{AD} 1391-1520(0.68) \\
\mathrm{AD} 1571-1626(0.21) \\
\mathrm{AD} 1316-1346(0.11)\end{array}$ & $\begin{array}{l}\text { Davis and Gipson } \\
\text { 1060; Tamers et al. } \\
1964\end{array}$ \\
\hline UR133 & $\begin{array}{l}\text { N184-E402, lev. } \\
4 \text { [terrace area } \\
\text { midden }\end{array}$ & TX-7989 & $578 \pm 118$ & $\begin{array}{l}554 \pm 118 \\
(-26.50 / 00)\end{array}$ & $\mathrm{AD} 1295-1455(1.00)$ & Nichols et al. 1995 \\
\hline \multicolumn{7}{|c|}{ possibly WHELAN PHASE (after Thurmond 1990) } \\
\hline \multirow[t]{2}{*}{ CP8 } & $\begin{array}{l}\text { submound struc- } \\
\text { ture, charred } \\
\text { pole in md. fill }\end{array}$ & Tx-199 & $320 \pm 60$ & $320 \pm 72$ & $\begin{array}{l}\mathrm{AD} 1490-1605(0.76) \\
\mathrm{AD} 1613-1649(0.24)\end{array}$ & $\begin{array}{l}\text { Tunnell 1959; } \\
\text { Pearson et al. } 1965\end{array}$ \\
\hline & $\begin{array}{l}\text { submound struc- } \\
\text { ture, charred } \\
\text { pole in md. fill }\end{array}$ & Tx-202 & $240 \pm 90$ & $240 \pm 99$ & $\begin{array}{l}\mathrm{AD} 1724-1816(0.34) \\
\mathrm{AD} 1621-1696(0.29) \\
\mathrm{AD} 1515-1592(0.24)\end{array}$ & $\begin{array}{l}\text { Tunnell 1959; } \\
\text { Pearson et al. } 1965\end{array}$ \\
\hline CP5 & Burial 10 fill & Tx-666 & $360 \pm 70$ & $360 \pm 81$ & $\begin{array}{l}\text { AD 1536-1635 (0.63) } \\
\text { AD 1473-1530 (0.37) }\end{array}$ & Tumer 1978 \\
\hline \multirow[t]{3}{*}{ TT182 } & Feature $\mathrm{Cl}$ & $\begin{array}{l}\text { Beta- } \\
44786\end{array}$ & $220 \pm 80$ & $220 \pm 80$ & $\begin{array}{l}\mathrm{AD} 1717-1819(0.46) \\
\mathrm{AD} 1634-1703(0.30)\end{array}$ & Kotter et al. 1991 \\
\hline & Feature C5 & $\begin{array}{l}\text { Beta- } \\
44787\end{array}$ & $290 \pm 120$ & $290 \pm 120$ & $\begin{array}{l}\mathrm{AD} 1465-1680(0.81) \\
\mathrm{AD} 1759-1803(0.14)\end{array}$ & Kotter et al. 1991 \\
\hline & $\begin{array}{l}\text { Zone } 2 \\
\text { (humates) }\end{array}$ & $\begin{array}{l}\text { Beta- } \\
44789\end{array}$ & $320 \pm 70$ & $320 \pm 70$ & $\begin{array}{l}\mathrm{AD} 1492-1605(0.76) \\
\mathrm{AD} 1613-1649(0.24)\end{array}$ & Kotter et al. 1991 \\
\hline TT392 & $\begin{array}{l}\text { N501-E476, } \\
\text { level } 3\end{array}$ & $\begin{array}{l}\text { Beta- } \\
64977\end{array}$ & $320 \pm 80$ & $\begin{array}{l}300 \pm 80 \\
(-26.10 / 00)\end{array}$ & $\mathrm{AD} 1483-166691.00)$ & Nash et al. 1995 \\
\hline
\end{tabular}


Volume 7, Number 4

Table 1 (continued). Late Caddoan Radiocarbon Dates from the Northeast Texas Pineywoods and Post Oak Savanna.

\begin{tabular}{|c|c|c|c|c|c|c|}
\hline Ske & Provenilence & Lab\# & $\begin{array}{l}{ }^{14} \text { C Age } \\
\text { (B.P.) }\end{array}$ & $\begin{array}{c}\text { Corrected Age } \\
\text { (B.P.) }\end{array}$ &  & Reference \\
\hline TT672 & Feature 1 & $\begin{array}{l}\text { Beta- } \\
\mathbf{8 0 4 3 2}\end{array}$ & $430 \pm 50$ & $\begin{array}{l}430 \pm 50 \\
(-25.90 / 00)\end{array}$ & $\begin{array}{l}\mathrm{AD} 1431-1510(0.90) \\
\mathrm{AD} 1602-1615(0.10)\end{array}$ & Dixon et al. 1995 \\
\hline \multirow[t]{2}{*}{ UR 118} & $\begin{array}{l}\text { BHT 46, or- } \\
\text { ganics on sherd }\end{array}$ & $\begin{array}{l}\text { Beta- } \\
72372\end{array}$ & $300 \pm 60$ & $\begin{array}{l}300 \pm 60 \\
(-27.30 / 00)\end{array}$ & $\begin{array}{l}\text { AD 1624-1679 }(0.40) \\
\text { AD 1518-1591 (0.32) }\end{array}$ & Nichols et al. 1995 \\
\hline & $\begin{array}{l}\text { N123/E143, } \\
\text { N118/E131 }\end{array}$ & $\begin{array}{l}\text { Beta- } \\
90532\end{array}$ & $440 \pm 40$ & $\begin{array}{l}440 \pm 40 \\
(-25.0 \mathrm{o} / 00)\end{array}$ & AD $1430-1483(1.00)$ & Unpublished \\
\hline UR129 & $\begin{array}{l}\text { N198-E211 } \\
\text { (humates) }\end{array}$ & Tx-7990 & $403 \pm 41$ & $\begin{array}{l}458 \pm 41 \\
(-21.60 / 00)\end{array}$ & $\mathrm{AD} 1425-1470(1.00)$ & Nichols et al. 1995 \\
\hline UR133 & BS6/BS7 & $\begin{array}{l}\text { Beta- } \\
90534\end{array}$ & $360 \pm 40$ & $\begin{array}{l}360 \pm 40 \\
(-25.0 \mathrm{o} / 00)\end{array}$ & $\begin{array}{l}\mathrm{AD} 1562-1630(0.61) \\
\mathrm{AD} 1480-1523(0.39)\end{array}$ & Unpublished \\
\hline \multirow[t]{2}{*}{ UR144 } & $\begin{array}{l}\text { Feaature 1, } \\
\text { bumed lens at } \\
\text { contact between } \\
\text { md fills }\end{array}$ & $\begin{array}{l}\text { Beta- } \\
84435\end{array}$ & $390 \pm 60$ & $\begin{array}{l}340 \pm 60 \\
(-28.30 / 00)\end{array}$ & $\begin{array}{l}\text { AD 1495-1605 (0.83) } \\
\text { AD 1613-1636(0.17) }\end{array}$ & Pertula et al. 1996 \\
\hline & $\begin{array}{l}\text { Feature 1, } \\
\text { bumed lens }\end{array}$ & $\begin{array}{l}\text { Beta- } \\
844436\end{array}$ & $310 \pm 60$ & $\begin{array}{l}270 \pm 60 \\
(-27.40 / 00)\end{array}$ & $\begin{array}{l}\text { AD 1515-1592 (0.42) } \\
\text { AD 1621-1675 (0.39) }\end{array}$ & Perttula ot al. 1996 \\
\hline WD529 & trash midden & $T x-3473$ & $480 \pm 80$ & 480 上 90 & $\mathrm{AD} 1393-1515(0.82)$ & $\begin{array}{l}\text { Bruseth and Perttula } \\
1981\end{array}$ \\
\hline
\end{tabular}

Key to Table 1 (Note: All site numbers are preceded by "41").

* Age not calibrated; delta ${ }^{13} \mathrm{C}$ values in parentheses. Assays on nutshell and wood charcoal

${ }^{13} \mathrm{C}$ values use the value estimates for fractionation correction suggested by Stuiver and Reimer (1993a:Table 1), namely -25.0 o/oo. These particular assays have standard deviations that include an error in the estimated delta ${ }^{13} \mathrm{C}$.

** Calibrations use bidecadal record of Stuiver and Reimer (1993a, 1993b), using CALIB 3.03c, Test 10; probability distributions are in parentheses.

good Titus phase contexts at 41TT182, 41TT392, 41TT672, 41UR118, and 41UT144 consistently span the period from cal $\mathrm{AD} 1431$ - 1680; a Period 3 (Perttula 1992; after ca. A.D. 1550) burial from Tuck Carpenter (Turner 1978) dates at 1-sigma to cal $\mathrm{AD}$ 1536-1635. Two other Titus phase radiocarbon assays (from 41UR118 and 41UR129) range in date from cal $\mathrm{AD} 1425$ - 1470 (Table 1).
It is interesting to note that the radiocarbon dates obtained in the $1960 \mathrm{~s}$ from Whelan phase mound sites fall into two clusters: one spanning the period from cal $\mathrm{AD} 1382$ - 1520, and the other ranging in the period from cal AD 1444 - 1668, the latter more or less the same span as the Camp Joy radiocarbon and OCR dates. The latter cluster, with two dates from Harroun, and one from Sam Roberts 
(Table 1), is contemporaneous with those discussed above from Titus phase domestic and mound-building contexts, although the dates from Harroun have been rejected by Thurmond $(1990: 204)$ on the grounds of their ceramic associations.

At Sam Roberts, although there is a Titus phase component in one areas of the site and the calibrated date from the submound structure dates to the same period, Thurmond (1990:144) argues that the mound was built during the preceding Whelan phase because "there is no clearly demonstrated instance of mound building in a Titus phase contexts". The two $16^{\text {th }}$ and $17^{\text {th }}$ century radiocarbon dates we have discussed from a burned structure in the Camp Joy Mound, along with the OCR dates of $300 \pm 10 \mathrm{BP}$ and $420 \pm 12 \mathrm{BP}$ from the same charcoal/daub lens, indicate the temporal context of the period of construction of the Sam Roberts mound should be reevaluated, as should the notion that Titus phase Caddoan groups did not build and/or use mounds.

Only a single radiocarbon date has been obtained from what is thought to be a Whelan phase domestic context, cal AD 1295 - 1455 from the Rookery Ridge site (41UR133) at the proposed Lake Gilmer (Table 1). The terrace area at 41UR1133 has a buried, single-component occupation with Pease Brushed-Incised jars, Ripley Engraved vessel sherds with the continuous scroll motif, and a Perdiz arrowpoint (Nichols et al. 1995: Table 172). These are characteristic of Period 1 (ca. A.D. 1350 - 1450) or Whelan phase occupations in the Cypress Cluster (Perttula 1992:248 and Table A-2).

\section{Summary}

Radiocarbon and OCR dates from the Camp Joy Mound strongly suggest that the mound was built and used in Late Caddoan period times, with the final use of the mound (followed by its being capped with a small, second, earthen platform) occurring during the $16^{\text {th }}$ and $17^{\text {th }}$ centuries. Other Late Caddoan radiocarbon dates from Northeast Texas indicate that the Whelan phase dates from about A.D. 1350 -1450 , and the following Titus phase - when the Camp Joy Mound was in use dating from $c a$. A.D. $1450-1680$. The general concordance in results between the radiocarbon and OCR dates is quite encouraging, and we advocate the combined use of both methods of dating archeological features as a beneficial means for Caddoan archeologists to secure reliable and culturally relevant dates on prehistoric and historic Caddoan sites throughout the Caddoan archeological area. 
Volume 7, Number 4

\section{References Cited}

Bruseth, James E., and Timothy $\mathrm{K}$. Perttula

1981 Prehistoric Settlement patterns at Lake Fork Reservoir. Texas Antiquities Permit Series, Report No. 2. Texas Antiquities Committee and Southern Methodist University, Austin and Dallas.

Davis, E. Mott, and J. R. Gipson 1960 The Dalton Site: A Late Caddoan mound Site in the Ferrell's Bridge Reservoir Area, Northeastern Texas. Submitted to National park Service, Contract No. 14-10-333-242, by division of Research in Anthropology, The University of Texas at Austin.

Dixon, Boyd, Elizabeth Skokan, Roabaert

Rogers, Steve Kotter, Michael Nash, and Edward Barnhart

1995 Archaeological Testing of Site $41 T T 672$ and Geomorphological Exploration of Tankersley and Dragoo Creek Drainages, Titus County, Texas. Document No. 950565. Espey, Huston \& Associates, Inc., Austin.

Frink, Douglas J.

1994 The Oxidizable Carbon Ratio ()CR):

A Proposed Solution to Some of the Problems Encountered with Radiocarbon Data. North American Archaeologist 15(1):17-29.

Jelks, Edward B., and Curtis D. Tunnell 1959 The Harroun Site: A Fulton Aspect
Component of the Caddoan Area, Upshur County, Texas. Archaeology Series, Nor. 2. Department of Anthropology, The University of Texas, Austin.

Kotter, Steven M., Laura Jones, Charles Frederick, and Wayne Glander 1991 An Archaeological Investigation of $41 T T 182$ in the Monticello-Winfield South Surface Mine, Titus County, Texas. Document No. 910264. Espey, Huston \& Associates, Inc., Austin.

Nash, Michael A., Steven M. Kotter, Kathryn V. Reese-Taylor, Elizabeth A. Skokan, E.R. Foster, Robert M. Rogers, and Wayne P. Glander

1995 National Register Testing of Ten

Sites in the Monticello B-2 Surface

Mine, Titus County, Texas. Review

Draft. Document No. 930529. Espey, Huston \& Associates, Inc., Austin.

Nichols, Peter, Larry Banks, Martha D. Freeman, Mark Parsons, Bert Rader, and David Shanabrook

1995 Test Excavations at Proposed

Lake Gilmer, Upshur County,

Texas. Horizon Environmental

Services, Inc., Austin.

Pearson, F.J., Jr., E. Mott Davis, and Murray A. Tamers

1966 University of Texas Radiocarbon Dates IV. Radiocarbon 8:453-466. 
Pearson, F.J., Jr., E. Mott Davis, Murray

A. Tamers, and R. W. Johnston

1965 University of Texas Radiocarbon

Dates III. Radiocarbon 7:296-314.

Perttula, Timothy $\mathrm{K}$.

1992 "The Caddo Nation": Archaeological and Ethnohistoric Perspectives. University of Texas Press, Austin.

Perttula, Timothy K., Bo Nelson, and Mike Turner

1996 Initial Report on Archeological Investigations at Lake $o$ ' the Pines, a U.S. Army Corps of Engineers-Owned Lake Facility in Northeast Texas. Friends of Northeast Texas Archaeology, Pittsburg and Austin.

\section{Story, Dee Ann}

1990 Cultural History of the Native Americans. In The Archeology and Bioarcheology of the Gulf Coastal Plain, by Dee Ann Story, Janice A. Guy, Barbara A. Burnett, Martha D. Freeman, Jerome C. Rose, D. Gentry Steele, Ben W. Olive, and Karl J. Reinhard, pp. 163-166. Research Series No. 38. Arkansas Archeological Survey, Fayetteville.

Stuiver, Minze, and Paula J. Reimer 1993a CALIB User's Guide Rev 3.0.3A for Macintosh Computers. Quaternary Research Center, University of Washington, Seattle. 1993b Extended ${ }^{14} \mathrm{C}$ Data Base and Revised CALIB $3.0 \quad{ }^{14} \mathrm{C}$ Age Calibration Program. Radiocarbon 35(1):215-230.

Tamers, Murray A., F.J. Pearson, Jr., and E. Mott Davis

1964 University of Texas Radiocarbon Dates II. Radiocarbon 6: 138-159.

\section{Thurmond, J. Peter}

1990 Archeology of the Cypress Creek Drainage Basin, Northeastern Texas and Northwestern Louisiana. Studies in Archaeology, No. 5. Texas Archeological Research Laboratory, The University of Texas at Austin, Austin.

Tunnell Curtis D.

1959 The Sam Roberts Site, Ferrell's Bridge Reservoir, Texas. MS on file, Texas Archeological Research Laboratory, The University of Texas at Austin, Austin.

Turner, Mike

1993 A Two-Phase Caddo Mound at the Camp Joy Site (41UR144). Notes on Northeast Texas Archaeology 2:66-75.

Turner, Robert L.

1978 The Tuck Carpenter Site and its Relation to Other Sites Within the Titus Focus. Bulletin of the Texas Archeological Society 49:1-110. 